\title{
Time to parathyroid function recovery in patients with protracted hypoparathyroidism after total thyroidectomy
}

\section{Inés Villarroya-Marquina, Juan Sancho, Leyre Lorente-Poch, Lander Gallego-Otaegui and Antonio Sitges-Serra}

Endocrine Surgery Unit, Hospital del Mar, Departament de Cirurgia, Universitat Autònoma de Barcelona, Barcelona, Spain
Correspondence

should be addressed

to A Sitges-Serra

Email

asitges@hospitaldelmar.cat

\begin{abstract}
Objective: Hypocalcaemia is the most common adverse effect after total thyroidectomy. It recovers in about two-thirds of the patients within the first postoperative month. Little is known, however, about recovery of the parathyroid function (RPF) after this time period. The aim of the present study was to investigate the time to RPF in patients with protracted (>1 month) hypoparathyroidism after total thyroidectomy.

Design: Cohort prospective observational study.

Methods: Adult patients undergoing total thyroidectomy for goitre or thyroid cancer. Cases with protracted hypoparathyroidism were studied for RPF during the following months. Time to RPF and variables associated with RPF or permanent hypoparathyroidism were recorded.

Results: Out of 854 patients undergoing total thyroidectomy, 142 developed protracted hypoparathyroidism. Of these, 36 (4.2\% of the entire cohort) developed permanent hypoparathyroidism and 106 recovered: 73 before 6 months, 21 within 6-12 months and 12 after 1 year follow-up. Variables significantly associated with RPF were the number of parathyroid glands remaining in situ (not autografted nor inadvertently resected) and a serum calcium concentration $>2.25 \mathrm{mmol} / \mathrm{L}$ at one postoperative month. Late RPF ( $>6$ months) was associated with surgery for thyroid cancer. RPF was still possible after one year in patients with four parathyroid glands preserved in situ and serum calcium concentration at one month $>2.25 \mathrm{mmol} / \mathrm{L}$.

Conclusions: Permanent hypoparathyroidism should not be diagnosed in patients requiring replacement therapy for more than six months, especially if the four parathyroid glands were preserved.
\end{abstract}

\section{Introduction}

Permanent hypoparathyroidism after thyroidectomy represents the last stage of postoperative parathyroid failure. Even though hypoparathyroidism was designated as an orphan disease by the European Commission in 2014 (1), it is currently considered as the most common permanent complication of total thyroidectomy.

Lorente-Poch et al. (2) defined the different syndromes of postoperative parathyroid failure as follows: (a) postoperative hypocalcaemia: serum calcium
() 2018 European Society of Endocrinology Printed in Great Britain concentration $<2 \mathrm{mmol} / \mathrm{L}(<8 \mathrm{mg} / \mathrm{dL})$ within $24 \mathrm{~h}$ after thyroidectomy; (b) protracted hypoparathyroidism: lowserum iPTH $(<1.4 \mathrm{pmol} / \mathrm{L}$ or $<13 \mathrm{pg} / \mathrm{mL})$ and need for calcium and vitamin D replacement at 4-6 weeks after surgery; (c) permanent hypoparathyroidism: low-serum iPTH and need for calcium and vitamin D replacement 1 year after total thyroidectomy.

There is, however, a lack of consensus regarding the follow-up period necessary to make a firm diagnosis 
of permanent hypoparathyroidism. The European Guidelines (3) define permanent hypoparathyroidism as a low-serum iPTH concentration and/or need for replacement therapy after six postoperative months, whereas the American Association of Clinical Endocrinologists (4) extends the follow-up period to one year. In fact, there is little empirical evidence to establish the follow-up time required to confirm the definitive loss of the parathyroid function after thyroidectomy. The issue has clinical relevance since a diagnosis of permanent hypoparathyroidism implies lifelong medical treatment, imposes an economical burden and may impact on the quality of life $(5,6)$.

Most studies on the recovery of the parathyroid function (RPF) after thyroidectomy are limited in sample size and/or report a short observation time after surgery $(7,8,9)$. Some anecdotal reports (10) have shown that RPF may take place more than one year after thyroidectomy.

The aim of this study was to determine the prevalence and timing of RPF in patients with protracted postsurgical hypoparathyroidism and to identify variables associated with delayed (>6 months) RPF.

\section{Subjects and methods}

\section{Study design}

This was an observational prospective cohort study of consecutive patients undergoing total thyroidectomy for benign goitre or thyroid malignancy at the Endocrine Surgery Unit of the Hospital del Mar (Barcelona, Spain), a tertiary referral centre for endocrine surgery, between 2000 and 2014 where only a single experienced team performs thyroid surgery. A retrospective chart review of a prospectively maintained database was carried out. Eligibility criteria were adult patients ( $\geq 18$ year/old) undergoing first-time total thyroidectomy for either multinodular goitre or thyroid cancer. Exclusion criteria were associated parathyroidectomy, Dunhill or subtotal thyroidectomies (performed for asymmetrical goitre or Graves' disease), completion thyroidectomies and surgery for recurrent benign or malignant disease. The main outcome variables of the study were the prevalence of permanent hypoparathyroidism and the time to RPF. The secondary endpoint was to investigate factors influencing early ( $\leq 6$ months) or late ( $>6$ months) RPF. Consent to use anonymized data for clinical research was obtained together with the informed consent for thyroidectomy.

\section{Surgical technique}

All patients underwent total extracapsular thyroidectomy. Central compartment node dissection was performed in patients diagnosed with papillary or medullary thyroid cancer and selective modified radical lateral neck dissection was performed as clinically indicated.

Parathyroid glands were sought in their usual position. No effort was made to identify parathyroid glands located in non-orthotopic places. In all patients, identification of parathyroid glands was based solely on visual macroscopic features. Parathyroid glands that could not be preserved in situ were chopped into $1 \mathrm{~mm}^{3}$ fragments and autotransplanted into several pockets into the ipsilateral sternocleidomastoid muscle. (11) The number of parathyroid glands remaining in situ (PGRIS, not transplanted nor resected inadvertently) was calculated as previously reported (12) and patients were classified accordingly (PGRIS score 1-4).

\section{Data acquisition}

The following preoperative data were obtained: gender, age, clinical diagnosis, serum calcium and thyroid function tests. After histopathologic analysis, specimen weight, number of resected lymph nodes (if central or lateral neck compartment dissection was performed) and presence of parathyroid glands in the specimen were obtained. The following postoperative variables were recorded: serum calcium and iPTH concentration at $24 \mathrm{~h}$, calcium and calcitriol dosage at discharge and $\mathrm{iPTH}$, serum calcium, serum phosphate and thyroid function tests at 4-6 weeks after surgery and regularly thereafter in patients with protracted hypoparathyroidism.

Serum iPTH levels were determined using either an immunoradiometric second-generation assay using an iPTH IRMA assay (Scantibodies Laboratory, Santee, CA, USA) or a solid-phase, two-site chemiluminescent enzyme-labelled assay, IMMULITE 2000 Intact PTH assay (Siemens Healthcare Diagnostics Spain, Madrid, Spain). The normal range was $1.4-7.5 \mathrm{pmol} / \mathrm{L}$ and the detection limit was $0.4 \mathrm{pmol} / \mathrm{L}$.

\section{Patient management and follow-up}

Serum calcium and iPTH concentrations were determined $24 \mathrm{~h}$ after surgery. Replacement therapy was prescribed only to patients with hypocalcaemia (s-Ca $<2 \mathrm{mmol} / \mathrm{L}$ at $24 \mathrm{~h}$ ) in the form of 1.5-3 g/day of calcium carbonate and $0.5-1.5 \mu \mathrm{g} /$ day of calcitriol at the time of hospital discharge 
according to body weight and severity of hypocalcaemia. They were followed thereafter in the outpatient clinic until RPF or permanent hypoparathyroidism was diagnosed. RPF was defined as a normal value for iPTH in asymptomatic patients not requiring replacement therapy. Permanent hypoparathyroidism was diagnosed if serum iPTH was low $(<1.4 \mathrm{pmol} / \mathrm{L})$ or undetectable at the last follow-up visit and replacement therapy was still required. Specifically, patients with protracted hypoparathyroidism at one postoperative month were followed indefinitely until RPF or permanent hypoparathyroidism was diagnosed. Weaning off replacement therapy after one month was initiated when serum calcium concentration was $\geq 2.60 \mathrm{mmol} / \mathrm{L}$ and/or iPTH became detectable or showing a sustained increase.

\section{Statistical analysis}

Descriptive statistics were used to analyse the prevalence and characteristics of patients developing protracted hypoparathyroidism. A univariate analysis was performed comparing patients who recovered or did not recover from protracted hypoparathyroidism, and those who recovered before or after six months. The Kolmogorov-Smirnov test was used to assess the normal distribution of quantitative variables. Continuous and normally distributed variables are expressed as mean \pm s.D. and compared using Student's $t$-test for unpaired samples. Non-normally distributed variables are expressed as mean \pm S.E.M. and compared using the Mann-Whitney $U$ test. Dichotomous variables were compared using the $\chi^{2}$ or Fisher's exact test as appropriate. Binomial logistic regression analysis with predictors selected by a forward stepwise procedure was used to assess the risk factors for permanent hypoparathyroidism. Time to RPF was analysed using Kaplan-Meier survival curves and groups compared with the Log Rank (MantelCox) test. The statistical analysis was carried out using SPSS version 22.0 (IBM). Statistical significance was set at $P<0.05$.

\section{Results}

Figure 1 shows the flow chart of patients included in the study. Some 188 patients had thyroid cancer and of those, 115 (61\%) received ablative radioiodine therapy between three and six months after thyroidectomy. From the initial cohort, 142 patients with protracted hypoparathyroidism $(21 \mathrm{M}, 121 \mathrm{~F})$ were investigated. Of these, 106 patients (75\%) recovered the parathyroid function during follow-up and 36 (25\%) were diagnosed with permanent hypoparathyroidism. RPF took place within six months in $73 / 106$ patients (69\%), between six and twelve months in $21 / 106(20 \%)$ and beyond this time period in $12 / 106$ (11\%) patients.

\section{Outcome of parathyroid function after protracted hypoparathyroidism}

Table 1 shows the differences between patients who recovered or did not recover from protracted hypoparathyroidism. There was no difference in RPF between patients operated on for benign or malignant disease. The PGRIS score was significantly better in patients recovering the parathyroid function. No early biochemical parameter was predictive of the long-term parathyroid function. At one postoperative month, however, both normal-high serum calcium and detectable iPTH serum concentrations were associated with a higher proportion of RPF. Calcium and calcitriol dosages at the time of hospital discharge were higher (and significant for calcium) in patients with RPF. Serum calcium concentration at one month, however, did not correlate with the amount of replacement therapy. The multivariate analysis (Table 2) identified that the relevant independent variables predicting RPF were PGRIS score, serum calcium level at 1 month and a detectable iPTH (0.4-1.4 pmol/L) at 1 month.

\section{Early vs late RPF}

Thyroidectomy for cancer was the only significant clinical variable associated with RPF after six months (Table 3). This was independent of the PGRIS score and serum calcium and iPTH concentrations at 1 month. Patients recovering early had a better biochemical profile at one month suggesting a less severe parathyroid injury in this subgroup. In agreement with this, final iPTH concentrations were higher in patients recovering within six months.

Time to RPF or to diagnosis of permanent hypoparathyroidism is shown in Fig. 2. About two-thirds of the patients showed an early RPF ( $<6$ months) but onethird recovered after six months. Factors significantly favouring an early RPF were a detectable iPTH and a serum calcium concentration $>2.25 \mathrm{mmol} / \mathrm{L}$ at 1 month.

The different PGRIS groups had a rather parallel RPF rates during the first six months. Only the PGRIS 3 and 4 groups, however, had some chances of late RPF. No patient in the PGRIS 1-2 group recovered beyond one year (Fig. 2D). 


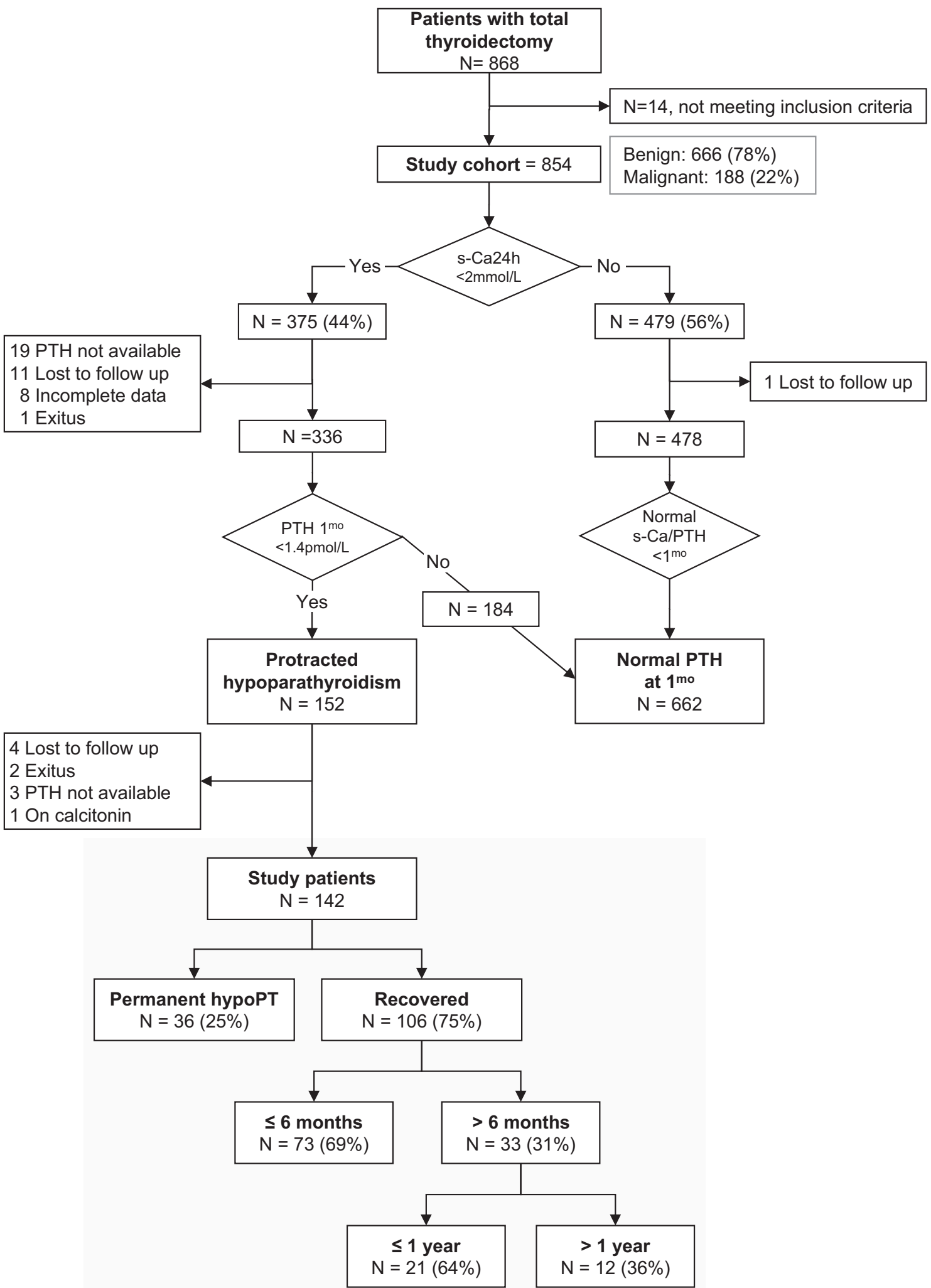

Figure 1 Patient flow diagram. Highlighted area encloses the study patients. Percentages are over the immediately preceding group. HypoPT, hypoparathyroidism; PTH, parathormone; S-Ca, serum calcium. 
Table 1 Demographic and disease-related variables of 142 patients with protracted hypoparathyroidism who did or did not recover the parathyroid function.*

\begin{tabular}{|c|c|c|c|}
\hline & $\begin{array}{l}\text { Recovered } \\
(n=106)\end{array}$ & $\begin{array}{c}\text { Permanent } \\
\text { hypoparathyroidism } \\
(n=36)\end{array}$ & $\boldsymbol{P}$ \\
\hline Age (years)** & $53 \pm 14$ & $54 \pm 15$ & 0.626 \\
\hline Gender, $n(\%)$ & & & 0.370 \\
\hline Male & $18(86)$ & $3(14)$ & \\
\hline Female & $88(73)$ & $33(27)$ & \\
\hline \multicolumn{2}{|c|}{ Indication for surgery, $n(\%)$} & & 0.298 \\
\hline Goitre & $72(72)$ & $28(28)$ & \\
\hline Malignancy & $34(81)$ & $8(19)$ & \\
\hline \multicolumn{4}{|c|}{ Associated procedure, $n(\%)$} \\
\hline \multicolumn{2}{|c|}{ Central neck dissection } & & 0.267 \\
\hline Yes & $28(82)$ & $6(18)$ & \\
\hline No & $78(66)$ & $30(34)$ & \\
\hline \multicolumn{2}{|c|}{ Lateral neck dissection } & & 0.978 \\
\hline Yes & $8(80)$ & $2(20)$ & \\
\hline No & $98(74)$ & $34(26)$ & \\
\hline $\begin{array}{l}\text { No. of lymph nodes } \\
\text { resected }\end{array}$ & $5 \pm 1$ & $3 \pm 1$ & 0.835 \\
\hline Specimen weight (g) & $79 \pm 7$ & $77 \pm 11$ & 0.847 \\
\hline \multicolumn{2}{|l|}{ PGRIS*** score, $n(\%)$} & & 0.014 \\
\hline $1-2$ & $12(63)$ & $7(37)$ & \\
\hline 3 & $36(66)$ & $19(34)$ & \\
\hline 4 & $57(86)$ & $9(14)$ & \\
\hline $\begin{array}{l}\text { s-Ca preop } \\
(\mathrm{mmol} / \mathrm{L})^{* *}\end{array}$ & $2.34 \pm 0.1$ & $2.30 \pm 0.2$ & 0.123 \\
\hline $\begin{array}{l}\mathrm{s}-\mathrm{Ca}^{24 \mathrm{~h}} \text { postop } \\
(\mathrm{mmol} / \mathrm{L})\end{array}$ & $1.87 \pm 0.02$ & $1.85 \pm 0.03$ & 0.326 \\
\hline $\mathrm{s}-\mathrm{Ca} \mathrm{a}^{1 \mathrm{month}}(\mathrm{mmol} / \mathrm{L})$ & $2.38 \pm 0.02$ & $2.14 \pm 0.05$ & 0.001 \\
\hline $\begin{array}{l}<2.25 \mathrm{mmol} / \mathrm{L}, n \\
(\%)^{\star * * *}\end{array}$ & $20(51)$ & $19(49)$ & 0.001 \\
\hline $\begin{array}{l}\geq 2.25 \mathrm{mmol} / \mathrm{L}, n \\
(\%)\end{array}$ & $82(86)$ & $13(14)$ & \\
\hline $\begin{array}{l}\mathrm{PTH}^{24 h} \text { postop } \\
(\mathrm{pmol} / \mathrm{L})\end{array}$ & $0.10 \pm 0.04$ & $0.04 \pm 0.03$ & 0.603 \\
\hline $\mathrm{PTH}^{1 \mathrm{month}}(\mathrm{pmol} / \mathrm{L})$ & $0.58 \pm 0.04$ & $0.39 \pm 0.06$ & 0.009 \\
\hline $\begin{array}{l}\text { Detectable } \\
(>0.4 \mathrm{pmol} / \mathrm{L}) * * * *\end{array}$ & $66(87)$ & $11(13)$ & 0.001 \\
\hline $\begin{array}{l}\text { Undetectable } \\
\text { ( } \leq 0.4 \mathrm{pmol} / \mathrm{L})\end{array}$ & $40(63)$ & $25(37)$ & \\
\hline Last PTH (pmol/L) & $2.97 \pm 0.17$ & $0.57 \pm 0.07$ & 0.001 \\
\hline Follow-up (days) & $828 \pm 113$ & $2216 \pm 270$ & 0.001 \\
\hline Days until recovery & $192 \pm 20$ & - & \\
\hline $\begin{array}{l}\text { Calcium dosage at } \\
\text { discharge }(\mathrm{g} / 24 \mathrm{~h})\end{array}$ & $2.8 \pm 0.08$ & $2.5 \pm 0.2$ & 0.033 \\
\hline $\begin{array}{l}\text { Calcitriol dosage at } \\
\text { discharge }(\mu \mathrm{g} / 24 \mathrm{~h})\end{array}$ & $0.76 \pm 0.04$ & $0.65 \pm 0.08$ & 0.213 \\
\hline
\end{tabular}

The relationship between serum calcium and iPTH concentrations at one month in 142 patients with protracted hypoparathyroidism is shown in Fig. 3. No correlation was found between these two variables for any of the three groups of patients. Sixteen patients had
Table 2 Multivariate analysis for permanent vs recovery from protracted hypoparathyroidism.*

\begin{tabular}{|c|c|c|c|c|}
\hline Predicted variable & OR & IL $(95 \%)$ & SL $(95 \%)$ & $\boldsymbol{P}$ \\
\hline \multicolumn{5}{|l|}{ Permanent hypoPT } \\
\hline PGRIS (1-4) & 0.331 & 0.170 & 0.646 & 0.001 \\
\hline $\begin{array}{l}\text { Serum calcium }{ }^{1 \text { month }} \\
(\mathrm{mg} / \mathrm{dL})\end{array}$ & 0.205 & 0.100 & 0.419 & 0.001 \\
\hline $\begin{array}{l}\text { Detectable iPTH }{ }^{1 \text { month }} \\
\text { (1 if Yes) }\end{array}$ & 0.105 & 0.031 & 0.350 & 0.001 \\
\hline
\end{tabular}

*Stepwise forward conditional binomial logistic regression.OR, odds ratio; IL, inferior limit; SL, superior limit.

a serum calcium concentration $\geq 2.62 \mathrm{mmol} / \mathrm{L}$ associated with low or undetectable iPTH concentration. Of these, 10 recovered within six months (mean: $108 \pm 52$ days, range 49-140 days), 4 after six months and 2 developed permanent hypoparathyroidism. In these 10 patients with an early RPF, an inverse correlation was found between serum calcium and days to RPF $\left(R^{2}=0.55\right.$; $P<0.001)$.

\section{Discussion}

The definition of permanent hypoparathyroidism after total thyroidectomy is still under scrutiny since the timing of RPF and the variables that influence it are poorly understood. Data are accumulating to indicate that RPF is a dynamic process which may occur long after thyroidectomy. $(4,8,13)$ Evidence presented here confirms that a prolonged follow-up is essential before a diagnosis of permanent hypoparathyroidism can be made with certainty. A follow-up postoperative period of just six months may lead to overdiagnosis and overtreatment of this condition in as much as one-third of the patients with protracted hypoparathyroidism (5).

Two previous reports have presented evidence for long-term ( $>6$ months) RPF. Kim et al. (10) studied a cohort of 1467 total thyroidectomy patients for thyroid cancer; 22 patients (1.8\%) developed 'permanent' hypoparathyroidism, but five of these showed longterm RPF after a mean of 30 months. Factors associated with these late RPFs were not investigated. Ritter et al. (7) followed 1054 patients after total thyroidectomy, of whom $18 \%$ had transient hypoparathyroidism; $70 \%$ of the patients recovered within 2 months, $5 \%$ recovered between 6 and 12 months and 1.9\% showed permanent hypoparathyroidism. This study, however, had a short follow-up ( $\leq 1$ year); transient hypocalcaemia and protracted hypoparathyroidism patients were studied as 
Table 3 Demographic and disease-related variables of 106 patients recovering from protracted hypoparathyroidism within or beyond six months after total thyroidectomy.*

\begin{tabular}{|c|c|c|c|}
\hline & $\begin{array}{c}\leq 6 \text { months } \\
(n=73)\end{array}$ & $\begin{array}{c}>6 \text { months } \\
(n=33)\end{array}$ & $\boldsymbol{P}$ \\
\hline Age (years)** & $53 \pm 15$ & $53 \pm 13$ & 0.855 \\
\hline Gender, $n(\%)$ & & & 0.337 \\
\hline Male & $10(56)$ & $8(44)$ & \\
\hline Female & $63(71)$ & $25(29)$ & \\
\hline \multicolumn{2}{|c|}{ Indication for surgery, $n(\%)$} & & 0.014 \\
\hline Goitre & $55(76)$ & $17(24)$ & \\
\hline Malignancy & $18(53)$ & $16(47)$ & \\
\hline \multicolumn{4}{|c|}{ Associated procedure, $n(\%)$} \\
\hline \multicolumn{2}{|c|}{ Central neck dissection } & & 0.425 \\
\hline Yes & $16(60)$ & $11(40)$ & \\
\hline No & $57(72)$ & $22(28)$ & \\
\hline \multicolumn{2}{|c|}{ Lateral neck dissection $* * * *$} & & 0.251 \\
\hline Yes & $4(50)$ & $4(50)$ & \\
\hline No & $69(70)$ & $29(30)$ & \\
\hline $\begin{array}{l}\mathrm{N} \text { of lymph nodes } \\
\text { resected }\end{array}$ & $3.8 \pm 1$ & $6.6 \pm 2$ & 0.351 \\
\hline Specimen weight & $88 \pm 9$ & $61 \pm 10$ & 0.059 \\
\hline PGRIS score, $n(\%) * * * *$ & & & 0.453 \\
\hline $1-2$ & $10(83)$ & $2(17)$ & \\
\hline 3 & $25(70)$ & $11(30)$ & \\
\hline 4 & $37(65)$ & $20(35)$ & \\
\hline $\begin{array}{l}\text { s-Ca preop } \\
(\mathrm{mmol} / \mathrm{L}) * *\end{array}$ & $2.34 \pm 0.4$ & $2.37 \pm 0.2$ & 0.165 \\
\hline $\begin{array}{l}\mathrm{s}-\mathrm{Ca}^{24 \mathrm{~h}} \text { postop } \\
(\mathrm{mmol} / \mathrm{L})\end{array}$ & $1.87 \pm 0.02$ & $1.87 \pm 0.03$ & 0.865 \\
\hline $\mathrm{s}-\mathrm{Ca}{ }^{1 \text { month }}(\mathrm{mmol} / \mathrm{L})$ & $2.39 \pm 0.03$ & $2.39 \pm 0.03$ & 0.474 \\
\hline $\begin{array}{l}<2.25 \mathrm{mmol} / \mathrm{L}, n \\
(\%)^{* * * *}\end{array}$ & $17(85)$ & $3(15)$ & 0.052 \\
\hline$\underset{(\%)}{\geq 2.25 \mathrm{mmol} / \mathrm{L}, n}$ & $52(63)$ & $30(37)$ & \\
\hline $\begin{array}{l}\mathrm{PTH}^{24 \mathrm{~h}} \text { postop } \\
(\mathrm{pmol} / \mathrm{L})\end{array}$ & $0.09 \pm 0.05$ & $0.10 \pm 0.05$ & 0.403 \\
\hline PTH $^{1 \text { month }}(p m o l / L)$ & $0.63 \pm 0.04$ & $0.47 \pm 0.06$ & 0.033 \\
\hline $\begin{array}{l}\text { Detectable } \\
(>0.4 \mathrm{pmol} / \mathrm{L}) * * * *\end{array}$ & $50(76)$ & $16(24)$ & 0.049 \\
\hline $\begin{array}{l}\text { Undetectable } \\
(\leq 0.4 \mathrm{pmol} / \mathrm{L})\end{array}$ & $23(47)$ & $17(53)$ & \\
\hline Last PTH (pmol/L) & $3.21 \pm 0.22$ & $2.49 \pm 0.22$ & 0.046 \\
\hline Follow-up (days) & $622 \pm 124$ & $1258 \pm 220$ & 0.001 \\
\hline Days until recovery & $96 \pm 38$ & $405 \pm 45$ & 0.001 \\
\hline $\begin{array}{l}\text { Calcium dosage at } \\
\text { discharge }(\mathrm{g} / 24 \mathrm{~h})\end{array}$ & $2.8 \pm 0.1$ & $2.8 \pm 0.1$ & 0.456 \\
\hline $\begin{array}{l}\text { Calcitriol dosage at } \\
\text { discharge }(\mu \mathrm{g} / 24 \mathrm{~h})\end{array}$ & $0.73 \pm 0.04$ & $0.83 \pm 0.07$ & 0.182 \\
\hline
\end{tabular}

a single group, and used a vague hypoparathyroidism definition (PTH $<10 \mathrm{pg} / \mathrm{mL}$ after surgery).

A recent report (8) on factors that positively influence the RPF in patients with postoperative hypocalcaemia identified preoperative iPTH concentration of $>5 \mathrm{pmol} / \mathrm{L}$ and a $<88 \%$ drop after thyroidectomy as variables favouring early RPF. The authors suggest that these findings reflect both a better preoperative baseline parathyroid function and lesser degree of intraoperative parathyroid gland injury. They did not report, however, on the technical issues that influence the prevalence of postoperative hypocalcaemia and the RPF such as the extension of surgery, inadvertent parathyroidectomy (14) or autotransplantation rates.

The fact that RPF is a lengthy and dynamic process is further emphasized by the inability of early biochemical variables to predict permanent hypoparathyroidism. Immediate postoperative low/undetectable iPTH serum concentration is a good marker for the development of postoperative hypocalcaemia; its ability to predict protracted or permanent hypoparathyroidism, however, is very limited $(13,15,16,17)$.

The present study sheds new light on factors influencing timing to RPF. From a clinical standpoint, early RPF was more common if thyroidectomy had been performed for multinodular goitre and this was independent of the PGRIS score and the metabolic parameters, suggesting that RPF may be impaired and/or delayed by treatment with radioiodine. Guven et al. (18) investigated the parathyroid function at baseline and at several time intervals after high-dose radioiodine ablation $(100-150 \mathrm{mCi})$ in 19 patients after total thyroidectomy for differentiated thyroid cancer. Their study showed a $25 \%$ transient decline in iPTH concentrations around the sixth month after radioiodine treatment. This did not cause symptomatic hypocalcaemia but the authors suggest that radioiodine treatment in patients with a limited parathyroid reserve may well lead to parathyroid insufficiency. The possibility that radioiodine may interfere with the RPF deserves further research.

From the endocrine point of view, patients with low but detectable iPTH serum concentration at one month $(0.4<\mathrm{iPTH}<1.4 \mathrm{pmol} / \mathrm{L})$ recovered in greater proportion and faster than those with undetectable iPTH. RPF in patients with undetectable iPTH concentration depends more heavily on other variables such as PGRIS and a serum calcium concentration at one month $\geq 2.25 \mathrm{mmol} / \mathrm{L}$. The latter positively influences RPF after protracted hypoparathyroidism and allows some hope for patients with hypoparathyroidism lasting for one year. We have hypothesized that the favourable prognostic value of high-normal calcium concentration during the first weeks of postoperative parathyroid failure may be due to a parathyroid splinting effect (19), which holds that serum calcium concentrations in the upper normal range put at rest the injured/ischaemic parathyroid glands 
A

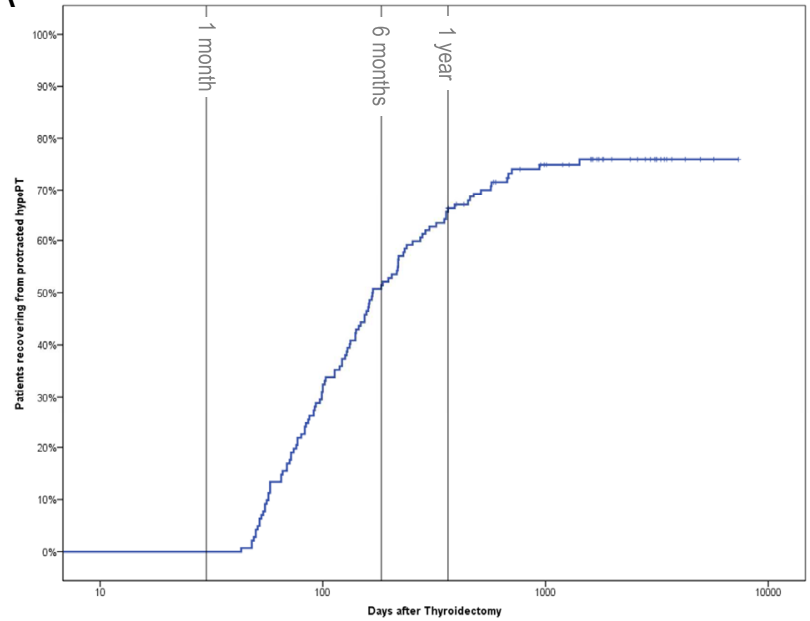

C

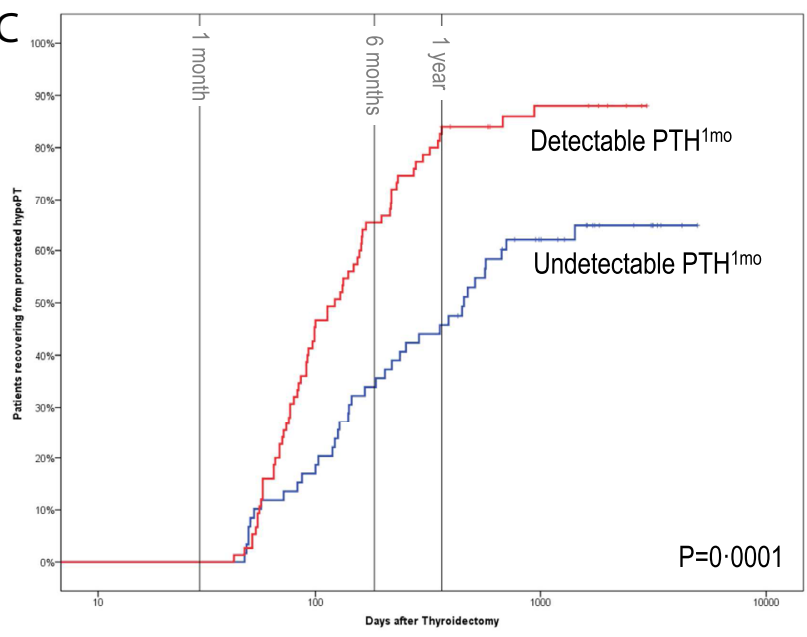

B

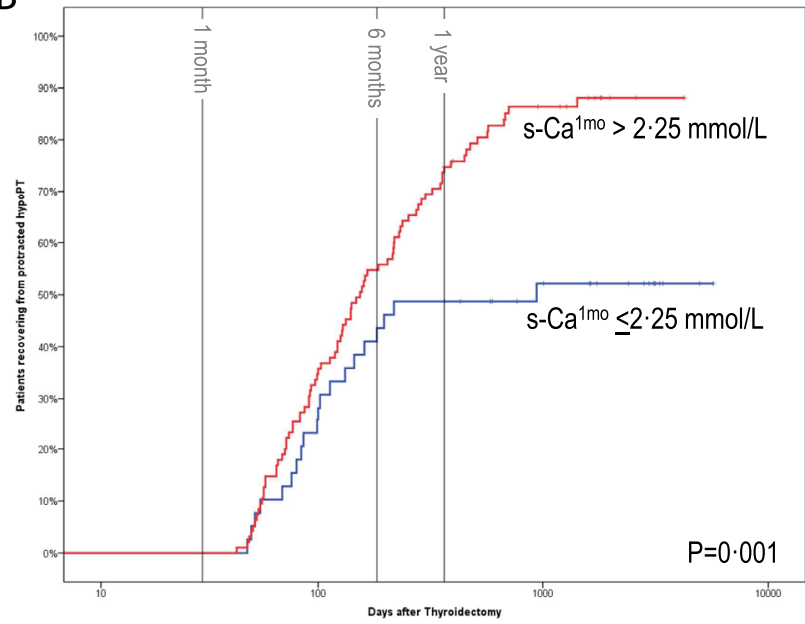

$\mathrm{D}$

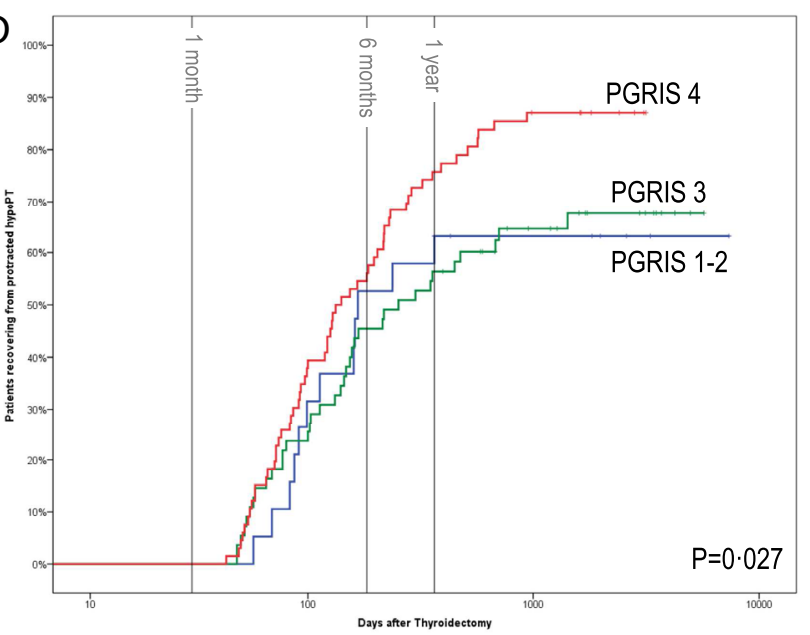

Figure 2

Time to recovery of the parathyroid function (RPF) in patients with protracted hypoparathyroidism. (A) Time to RPF for the whole cohort $(n=142)$. (B) RPF according to serum calcium concentration at one month. (C) RPF according to detectable vs undetectable parathormone at one month. (D) RPF according to PGRIS (parathyroid glands remaining in situ). Horizontal axis uses logarithmic scale (days). hypoPT, hypoparathyroidism. $P$ values from the Log Rank (Mantel-Cox) test.

and allow for a better recovery of the remaining viable parathyroid parenchyma from intraoperative injury. Data from the present study suggest that serum calcium concentrations at one month in patients with RPF were influenced by higher doses of calcium and calcitriol being prescribed at the time of hospital discharge. An alternate or complementary explanation of the beneficial effects of a normal-high serum calcium concentration could be that some patients might have been erroneously diagnosed with protracted hypoparathyroidism because low or undetectable iPTH at one month resulted from iatrogenic hypercalcaemia. No correlation was found, however, between serum calcium and iPTH. Moreover, in the group of hypercalcaemic protracted hypoparathyroidism patients that recovered the parathyroid function, an inverse correlation was found between serum calcium and days to RPF: patients with more elevated serum calcium concentrations recovered early than those with mild hypercalcaemia. Further studies are needed to clarify this multifaceted physiological riddle.

The third variable modulating RPF is the PGRIS score, which indirectly translates the amount of potentially viable remaining parathyroid tissue: a PGRIS 4 score predicts a significantly higher proportion of RPF. Although PGRIS did not positively influence an early recovery, patients with three or four parathyroid glands remaining in situ still have some chances of recovery after one year of replacement therapy. This means that surgeons should make all possible 


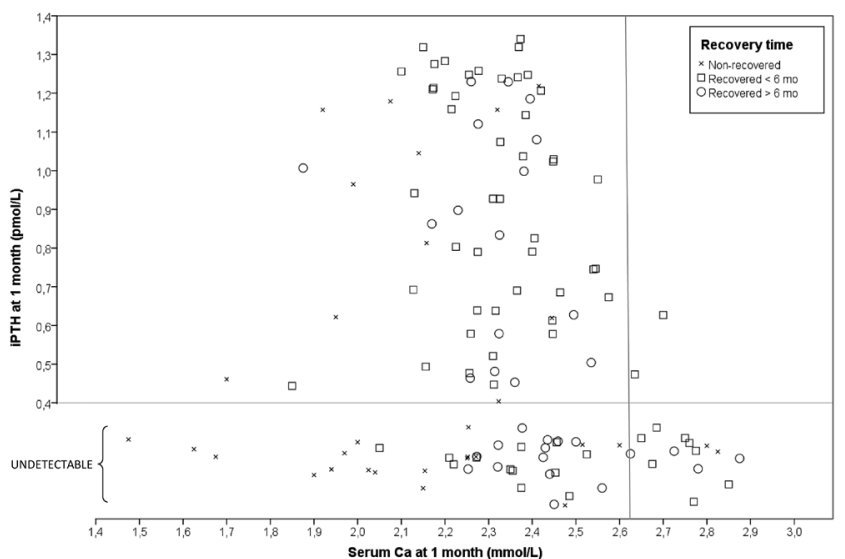

Figure 3

Serum calcium ( $\mathrm{mmol} / \mathrm{L})$ vs iPTH (pmol/L) in patients with protracted hypoparathyroidism at one month after total thyroidectomy. The vertical line at $2.62 \mathrm{mmol} / \mathrm{L}$ marks the upper limit of normal serum calcium concentration. Values of iPTH concentrations below $0.40 \mathrm{pmol} / \mathrm{L}$ are labelled as 'UNDETECTABLE' and plotted with randomly assigned iPTHN values between 0 and $0.39 \mathrm{pmol} / \mathrm{L}$.

efforts to preserve the parathyroid glands in situ avoiding autotransplantation, inadvertent parathyroidectomy and thymectomy $(12,14,20,21,22,23)$.

A limitation of the study is that $10 \%$ of the patients with postoperative hypocalcaemia were lost to follow-up before the final parathyroid status could be assessed. Our unit serves a geographical area that hosts a considerable proportion of mobile migrant population. We cautiously infer that most of the patients not coming back after the first postoperative visit at one week did not develop longterm calcium metabolism disturbances.

In conclusion, it is suggested that the average patient with hypocalcaemia after total thyroidectomy should be discharged on calcium and calcitriol to maintain serum calcium concentrations of at least $2.25 \mathrm{mmol} / \mathrm{L}$ during the first weeks. If he or she cannot be weaned off within the first month, RPF will mostly depend on the serum calcium concentrations achieved, PGRIS and whether iPTH is detectable or not. Permanent hypoparathyroidism should not be diagnosed if replacement therapy is still required six months after thyroidectomy, since up to one-third of the patients will recover beyond this time period and a few ones even after one year. Candidates for late RPF are those patients operated on for thyroid cancer in whom three or four glands were preserved in situ, with undetectable iPTH and serum calcium concentration in the normal upper range one month after total thyroidectomy.
Declaration of interest

The authors declare that there is no conflict of interest that could be perceived as prejudicing the impartiality of this study.

\section{Funding}

This research did not receive any specific grant from any funding agency in the public, commercial or not-for-profit sector.

\section{References}

1 EU/3/13/1210. European Medicines Agency 2015. Ema.europa.eu. N.p. 2017. (Website). (available at: http://www.ema.europa.eu/ema/ index.jsp?curl=pages/medicines/human/orphans/2014/01/human orphan_001301.jsp\&mid=WC0b01ac058001d12b). Accessed on 20 February 2017.

2 Lorente-Poch L, Sancho JJ, Muñoz-Nova JL, Sánchez-Velázquez P $\&$ Sitges-Serra A. Defining the syndromes of parathyroid failure after total thyroidectomy. Gland Surgery 20154 82-90. (https://doi. org/10.3978/j.issn.2227-684X.2014.12.04)

3 Bollerslev J, Rejnmark L, Marcocci C, Shoback DM, Sitges-Serra A, van Biesen W \& Dekkers OM. European Society of Endocrinology Clinical Guideline: Treatment of chronic hypoparathyroidism in adults. European Journal of Endocrinology 2015173 G1-G20. (https:// doi.org/10.1530/EJE-15-0628)

4 Stack BC Jr, Bimston DN, Bodenner DL, Brett EM, Dralle H, Orloff LA, Pallota J, Snyder SK, Wong RJ \& Randolph GW. American Association of Clinical Endocrinologists and American College of Endocrinology disease state clinical review: postoperative hypoparathyroidism definitions and management. Endocrine Practices 201521 674-685. (https://doi.org/10.4158/EP14462.DSC)

5 Underbjerg L, Sikjaer T, Mosekilde L \& Rejnmark L. Postsurgical hypoparathyroidism - risk of fractures, psychiatric diseases, cancer, cataract, and infections. Journal of Bone and Mineral Research 201429 2504-2510. (https://doi.org/10.1002/jbmr.2273)

6 Shoback DM, Bilezikian JP, Costa AG, Dempster D, Dralle H, Khan AA, Peacock M, Raffaelli M, Silva BC, Thakker RV et al. Presentation of hypoparathyroidism: etiologies and clinical features. Journal of Clinical Endocrinology and Metabolism $20161012300-2312$. (https://doi.org/10.1210/jc.2015-3909)

7 Ritter K, Elfenbein D, Schneider DF, Chen H \& Sippel RS. Hypoparathyroidism after total thyroidectomy: incidence and resolution. Journal of Surgical Research 2015197 348-353. (https:// doi.org/10.1016/j.jss.2015.04.059)

8 Al-Dhahri SF, Mubasher M, Mufarji K, Allam OS \& Terkawi AS. Factors predicting post-thyroidectomy hypoparathyroidism recovery. World Journal of Surgery 201438 2304-2310. (https://doi.org/10.1007/ s00268-014-2571-6)

9 Youngwirth L, Benavidez J, Sippel R \& Chen H. Parathyroid hormone deficiency after total thyroidectomy: incidence and time. Journal of Surgical Research 2010163 69-71. (https://doi.org/10.1016/j. jss.2010.03.059)

10 Kim SM, Kim HK, Chang H, Kim BW, Lee YS, Chang HS \& Park CS. Recovery from permanent hypoparathyroidism after total thyroidectomy. Thyroid 201525 830-833. (https://doi.org/10.1089/ thy.2014.0500)

11 Olson JA Jr, DeBendetti MK, Baumann DS \& Wells SA Jr. Parathyroid autotransplantation during thyroidectomy. Results of long-term follow-up. Annals of Surgery 1996223 472-478.

12 Lorente-Poch L, Sancho JJ, Ruiz S \& Sitges-Serra A. Importance of in situ preservation of parathyroid glands during total thyroidectomy. British Journal of Surgery 2015102 359-367. (https://doi.org/10.1002/ bjs.9676) 
13 Seo ST, Chang JW, Jin J, Lim YC, Rha KS \& Koo BS. Transient and permanent hypocalcemia after total thyroidectomy: early predictive factors and long-term follow-up results. Surgery 2015158 1492-1499. (https://doi.org/10.1016/j.surg.2015.04.041)

14 Sitges-Serra A, Gallego-Otaegui L, Suárez Lorente-Poch L, MartínezRuiz C \& Sitges-Serra A. Inadvertent parathyroidectomy during total thyroidectomy and central neck dissection for papillary thyroid carcinoma. Surgery 2017161 712-719. (https://doi.org/10.1016/j. surg.2016.08.021)

15 Selberherr A, Scheuba C, Riss P \& Niederle B. Postoperative hypoparathyroidism after thyroidectomy: efficient and cost-effective diagnosis and treatment. Surgery 2015157 349-353. (https://doi. org/10.1016/j.surg.2014.09.007)

16 Julián MT, Balibrea JM, Granada ML, Moreno P, Alastrué A, PuigDomingo M \& Lucas A. Intact parathyroid hormone measurement at 24 hours after thyroid surgery as predictor of parathyroid function at long term. American Journal of Surgery 2013206 783-789. (https:// doi.org/10.1016/j.amjsurg.2013.01.038)

17 Almquist M, Hallgrimsson P, Nordenström E \& Bergenfelz A. Prediction of permanent hypoparathyroidism after total thyroidectomy. World Journal of Surgery 201438 2613-2620. (https:// doi.org/10.1007/s00268-014-2622-z)

18 Guven A, Salman S, Boztepe H, Yarman S, Tanakol R, Azizierli H \& Alagol F. Parathyroid changes after high dose radioactive iodine in patients with thyroid cancer. Annals of Nuclear Medicine 200923 437-441. (https://doi.org/10.1007/ s12149-009-0270-4)

19 Sitges-Serra A, Ruiz S, Girvent M, Manjón H, Dueñas JP \& Sancho JJ. Outcome of protracted hypoparathyroidism after total thyroidectomy. British Journal of Surgery 201097 1687-1695.

20 Tartaglia F, Blasi S, Giuliani A, Merola R, Livadoti G, Krizzuk D, Tortorelli G \& Tromba L. Parathyroid autotransplantation during total thyroidectomy. Results of a retrospective study. International Journal of Surgery 2016 (Supplement 1) S79-S83. (https://doi.org/10.1016/j. ijsu.2015.05.059)

21 Kihara M, Miyauchi A, Kontani K, Yamauchi A \& Yokomise H. Recovery of parathyroid function after total thyroidectomy: longterm follow-up study. ANZ Journal of Surgery 200575 532-536. (https://doi.org/10.1111/j.1445-2197.2005.03435.x)

22 Lang BH, Chan DT \& Chow FC. Visualizing fewer parathyroid glands may be associated with lower hypoparathyroidism following total thyroidectomy. Langenbeck's Archives of Surgery 2016401 231-238. (https://doi.org/10.1007/s00423-016-1386-3)

23 Applewhite MK, White MG, Xiong M, Pasternak JD, Abdulrasool L, Ogawa L, Suh I, Gosnell JE, Kaplan EL, Duh QY et al. Incidence, risk factors, and clinical outcomes of incidental parathyroidectomy during thyroid surgery. Annals of Surgical Oncology 201623 4310-4315. (https://doi.org/10.1245/s10434-016-5439-1)

Received 16 July 2017

Revised version received 16 October 2017

Accepted 23 October 2017 